\title{
Quantifying a successful translation: A cognitive frame analysis of (un)translatability
}

\author{
Ingie Zakaria \\ Ain Shams University, Egypt
}

\begin{abstract}
Assessing the success of a translated text is one of the controversial topics often discussed in the field of translation studies. The definition of a so-called successful translation is itself controversial. Therefore, for the purpose of this study, the success of a given translation may be defined as transmitting a similar, though rarely identical, semantic frame reference in the Target Language (TL) as was intended by the Source Language (SL) and may be quantified by comparing alternate translations and choosing the one with the highest number of equivalent frame references. One of the factors which could be considered detrimental to the production of a successful translation, as defined above, is the (un)translatability of cultural terms. Cultural terms, defined here as expressions referring to concepts or entities that are unique to a certain culture, are believed to be untranslatable. This paper uses Arabic VISUAL frames referencing the Egyptian garment ğal-labiy-ya (or ğilbāb) as an example and argues that (un)translatability can be quantified using semantic frames based on the assumption that all SL terms have multiple frame references, some of which, mostly the ones indicating denotative meaning, have parallels in the TL while some others, mostly the ones indicating connotative meaning, do not. The degree of (un)translatability may, therefore, be quantifiable by observing which TL terms possess a higher rate of similar frame references in SL, which aids in the evaluation of translated texts in terms of relative equivalence and the degree to which the Target Text (TT) audience receives similar information to that received by the Source Text (ST) audience.
\end{abstract}

Keywords: Frame Semantics, Cognitive Semantics and Translation, VISUAL Frames, Translating Cultural Elements

\section{Introductory Notes}

\subsection{The Translation of Cultural Elements}

The translation of cultural elements, expressions denoting concepts or entities that are unique to a certain culture, presents an issue that seems to almost constantly yield opinions tending toward the conclusion that cultural elements are, to various degrees and for various reasons, untranslatable. However, the absolute untranslatability of cultural elements is disproved by the existence of hundreds of translated texts full of such elements. Though quality might be disputed, the fact that they are indeed translations is indisputable. Any text has a degree of 
untranslatability to it, whether it is cultural or linguistic; it can be claimed, however, that certain elements can never be translated adequately due to the limited existence of equivalent or, less ambitiously, similar semantic frames in the Source Language (SL), although adequacy remains relative.

The question, however, is not whether a term is translatable, but rather how translatable it is in the given context. The premise of this study is that there is a grey area between the fully translatable and the fully untranslatable where terms are partially translatable based on how many of the total number of SL frame references activated by the SL reader can be similarly activated by the Target Language (TL) reader. This means that the higher the percentage of TL frames activated by the TL reader that are also activated by the SL reader, the more successful the translation is considered. This gives translators, editors, and academics a mental gauge by which to assess the success of a TL text and attempt to augment its faithfulness to the SL text or otherwise identify the areas which are truly untranslatable and prioritize accordingly in terms of time and effort. Whereas past studies of the same topic focus on proving, or otherwise disproving the applicability of English-based frames in creating parallel lexicon fragments in other languages to be used in translation, the present study focuses on examining what happens when the English-based frames are not applicable.

\subsection{Semantic Frames and Translation: Lexicons and Typologies}

According to Boas (2013), the use of frame semantics to create translation resources, both for automated and manual translation, was largely motivated by the creation of the FrameNet Project (Lowe, Baker, \& Fillmore, 1997), an annotated, corpus-based English lexicon employing the principles of Frame Semantics. The idea was to create parallel annotated lexicons based on the original English lexicon in order to streamline the translation process, as suggested by Fillmore \& Atkins (2000), Petruck \& Boas (2003), and Boas (2002; 2003; 2005) (Boas, 2013). The process of creating parallel frame-based lexicon fragments based on English frames has been successfully performed in a diverse set of languages including Japanese (Ohara et al., 2004), Spanish (Subirats \& Petruck, 2003), and German (Burchardt et al., 2009), but Arabic has only been significantly subjected to small-scale, frame-based analyses as recently as 2009 (AbdulBaquee \& Atwell, 2009).

Although previous studies rely heavily and almost exclusively on FrameNet for their data analysis, the present work also introduces the semantic frame typology originally introduced by de Vega (1984), and later adapted by Rojo (2002 a\&b). This is due to the fact that FrameNet tags are a complex system designed primarily for artificial intelligence purposes. The typology used in this research, however, is a more simplified system targeting manual translators and proofreaders. Its hierarchical system makes it easier for a translator or a researcher in the field of manual translation to keep track of the frames used in the text, thus providing a fast and effective quantification tool.

De Vega identifies the five most basic frames as VISUAL (frames decoding visual perception, such as the content one normally sees within a room), SITUATIONAL (scripts) (frames indicating knowledge of common situations, such as going to school or the hairdresser), DOMAIN (frames 
guiding discourse production and understanding), SOCIAL (frames organizing social knowledge) and SELF-CONCEPT (frames indicating each person's perception of themselves). SOCIAL frames are furthermore divided into generic frames, such as 'intelligent person' or 'shy woman', and themes, such as social roles and relationships.

Rojo (2002 a\&b) uses Frame Semantics to analyze the translation of cultural elements and humor from Spanish into English through dividing the concepts in the Source Text (ST) into a frame typology and comparing it to the frames in the TT, which is also the method used in the present study. The frame typology employed in these studies is a modified version of de Vega's typology resulting in the following frames: VISUAL frames, SITUATIONAL frames, TEXT_TYPE frames, SOCIAL frames and GENERIC frames. She also divided de Vega's SOCIAL frame into four sub-types: INSTITUTIONAL frames (indicating systems created by society), GEOGRAPHICAL frames, SOCIAL STATUS frames, and INTERPERSONAL frames.

Of the aforementioned typology, the present study uses VISUAL frames in SL (Modern Standard Arabic) and TL (English) as an example of the semantic void resulting from frame incongruence between the two languages involved in the translation process. The present study also applies a modified version of the typology based on its more extensive data, where SOCIAL, GENERIC, and SITUATIONAL frames are the same, but TEXT_TYPE frames are expanded into TEXTUAL frames, which includes the sub-frames TEXT_TYPE and RHETORICAL_DEVICE, and VISUAL frames are expanded into PERCEPTUAL frames, under which various sensory/perceptual frames fall.

\subsection{What are VISUAL Frames?}

In the original frame typology (de Vega, 1984 and Rojo, 2002), the term visual frames was used independently to indicate the cognitive interpretation of the visual perception of objects and situations. For the purposes of this study, VISUAL frames are regarded as part of the larger, more extensive PERCEPTUAL frame in order to cover a wider spectrum of objects, situations, and events. In this case, PERCEPTUAL frames are decoded by what the reader has experienced through the use of the senses which form their knowledge of the physical world. Perception, including vision, is essentially one of the tenets of cognitive semantics. The ability of the brain to formulate descriptions of what it sees and hears, forming images of the world around it, indicates the close link between cognition and perception (Gärdenfors, 1999). When reading a text, the reader invokes knowledge of things previously seen, smelled, tasted, heard, or touched, in order to gain a full understanding of the information encoded within the text. In cases where the encoded PERCEPTUAL frame does not exist in the Target Text (TT) reader's repertoire, there will be a gap in the stream of information decoded throughout the processing of the TT.

It can be argued that perceptual universals exist in some cases where the encoded information is not exclusive to the SL and/or SC. For example, water is something that would be decodable to any reader, regardless of where they are from or which language has helped shape their knowledge of the world, since any reader can visualize the (usually) colorless, odorless fluid they use for drinking and washing. However, although it may seem a word like bird could receive the same treatment, since birds are rather ubiquitous creatures occurring 
almost everywhere, decoding a seemingly simple sentence like I saw a bird, even though it would receive the same translation رأيت طائرا raPaytu țāPiran, would involve the visualization of different birds in the cognitive process of text interpretation. This becomes more complicated with visual interpretations of such things as commercial brands, which may not be readily available in the Target Culture (TC), or things exclusive to the ST, such as a Middle Eastern dance or a Scottish haggis. In this case, instead of the cognitive, real-world property of perception being linked to the anchoring lexical item in the text, there exists a void where an image should be invoked. This could lead to one of two outcomes: (a) the item is undecodable to the TT reader due to its non-presence in their culture (and therefore in their linguistic repertoire) or (b) the item exists in a different form or manner from the one encoded in the ST, in which case the TT decodes a different, though sometimes relatively connected, form of knowledge than the one intended by the ST. For example, a North African reader might have issues decoding I saw an emu, which will not evoke the PERCEPTUAL frame of a large bird indigenous to Australia unless the reader has encountered the term or the bird prior to reading the text. On the other hand, the generic term bird will evoke images of different birds in the minds of different readers, depending on what is considered a generic bird in their SC.

\subsection{The Premise of the Study: Comparing VISUAL Frames}

The study is based on the assumption that each and every lexical unit in any given language possesses multiple layers of frame references, some of which, mostly the ones indicating denotative meaning, have parallels in the TL while some others, mostly the ones indicating connotative meaning, do not. The degree of (un)translatability may, therefore, be quantifiable by observing which TL terms possess a higher rate of similar frame references in SL, which aids in the evaluation of translated texts in terms of relative equivalence and the degree to which the Target Text (TT) audience receives similar information to that received by the Source Text (ST) audience.

The study uses data extracted from three modern Egyptian novels (Aunt Safiyya and the Monastery, Taxi, and Zaat) and their translations by three different translators. The different backgrounds of the Source Texts contribute to the richness of data and place it on a wider spectrum in terms of frame reference and translation. Aunt Safiyya and the Monastery is a modern classic set in Upper Egypt in the deep, often neglected South. It discusses unrequited love, honor, and vengeance against the backdrop of major events in Egyptian history. Zaat, a work of extremely dark humor chronicling the life of a lower-middle class Egyptian woman, also uses national headlines to frame the events of the novel, spanning across five decades and three presidents. Taxi is a part-Standard, part-Colloquial collection of stories largely based on the author's real-life conversations with taxi drivers in the Egyptian capital.

The methodology of the study may be summarized as follows:

1. Data is compiled from the three aforementioned texts, modern Egyptian novels and their translations by three different translators. 
2. A detailed analysis of both the ST and the TT is performed based on the proposed frame typology, detailing both primary PERCEPTUAL $\rightarrow$ VISUAL frames and secondary SOCIAL, SITUATIONAL, GENERIC, or TEXTUAL frames.

3. Frame reference equivalence, or the lack thereof, is quantified by comparing TL frames to SL frames and calculating the percentage of SL translatability.

4. Untranslatable frames are assessed and other options with a higher rate of equivalence are considered, where necessary.

5. If none exist and the rate is still inadequate, supplementation by such means as footnotes and/or paraphrase is considered.

\section{Data and Analysis: Gallabiyya and Jilbaab ${ }^{1}$}

Much like any concept or entity exclusive to a specific culture, traditional clothes common in the Source Culture (SC) may cause a lexical/perceptual gap in the TT due to the reader's inability to visualize them. Measuring the success of a translation involving an SL term that does not exist in the TL involves the prior knowledge that perfect equivalence is not possible. The objective in this case is, therefore, not to achieve a one hundred percent rate of identical frame reference, which would be possible in other cases, but rather to reach a combination of the highest possible degree of similarity plus the lowest possible degree of interference of TL reference, since the latter may lead to the SL, and therefore the SC reference to be lost in translation, thus compromising the quality of the cultural experience of the TL reader. A ğal-labiy-ya is a traditional rural garment worn by both men and women in Upper Egypt and the Delta of the Nile, in addition to the numerous variations worn in other Middle Eastern countries. The word ğal-labiy-ya is a more colloquial term, the standard term being ğilbā $b$. In Modern Standard Arabic, the word ğilbāb has no frame references other than those associated with GeneriC $\rightarrow$ UPPER_EgyPTIAN/Nile_Delta, PERCEPTUAL $\rightarrow$ VisUAL $\rightarrow$ ClOTHING_ITEM, and the appropriate MALE/FEMALE reference, depending on the person wearing it in the ST, in addition to a SOCIAL $\rightarrow$ SOCIAL_STATUS frame, since wearing a ğal-labiy-ya is often associated with the unurbanized, which, within the subculture and the modern trend towards urbanization, might indicate social inferiority.

The treatment of the term in all three texts highlights three different approaches to transferring the VISUAL frame from the SL into the TL, especially given the secondary frames involved in the analysis of the term. The following sections highlight this treatment and how the frame reference congruence rate and the interference of TL frame references impact the success of the final product.

\footnotetext{
This is the spelling used in the TTs, a simple, non-academic transliteration asymmetrically employing both the voiced plosive velar consonant $g$ characteristic of Egyptian Colloquial Arabic (ECA) and the voiced fricative post-alveolar consonant $\breve{g}$ characteristic of Modern Standard Arabic (MSA) as seen in the translation of Aunt Safiyya and the Monastery. The asymmetry, therefore, mirrors that of the TT. In cases where it does not directly refer to the exact words used in the TTs, the in-text transcription used in the present work relies on the standardized voiced fricative post-alveolar consonant $\breve{g}$ characteristic of transliterated Arabic in academic texts, which is based on Modern Standard Arabic (MSA).
} 


\subsection{Aunt Safiyya and the Monastery}

Aunt Safiyya and the Monastery is set in Upper Egypt. This leads to many of its lexical units being cultural terms deeply rooted in the GENERIC $\rightarrow$ UPPER_EGYPT frame, which itself carries numerous sub-frames and is accompanied by a number of adjacent frames under the main frame. The term ğilbāb, which the translator chooses to transliterate depending on the gender of the wearer, is a prime example of how misinterpreting one or more of the many sub-frames encoded by a certain term can result in misrepresenting the term in the TL and automatically causes the TL reader to decode a perceptually inaccurate, or completely different, image when reading the TT. As can be observed in the examples cited below, the translator uses ğilbā $b$ in reference to the garment when the wearer is male $(1,2,3)$ and ğal-labiy-ya when the wearer is female $(4,5,6)$, even when the SL term is ğilbāb in both cases:

(1)

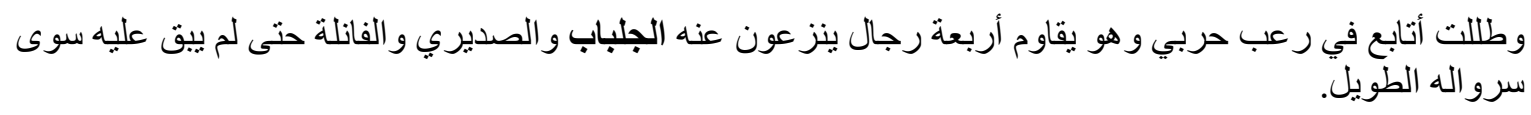

Wa zalaltu Putābifu fĩ ruSbin harbī wa huwa yuqāwimu ?arbaßati riǧālin yanzafūna Sanhu al-ğilbāba waș-ședīrīy-ya wal fanil-la ḥatta lam yabqa Salayhi siwā sirwālahu aț-țawīl

Terrified, I continued to follow Harbi with my eyes as he struggled with the four men who were stripping him of his gallabiyya, vest, and undershirt until nothing was left but his long underpants.

(2)

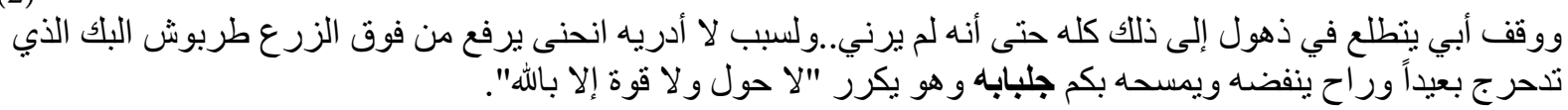

Wa waqafa Pabī yatațal-lâu fị dِuhūlin ?ilā deālika kul-lihi ḥat-ta ?an-nahū lam yaranī..wa li-sababin lā Padrīh inḥanā yarfåu men fawqi az-zarßi țarbūshi al-bīk al-lad̄i tadaḥrağa bafĩdan wa rāh yanfuḍuhu wa yamsaḥuhu bi-kum-mi ğilbābahu wa huwa yukar-rir "lā ḥawla walā quw-wata il-lā bil-lāh"

My father stopped, and stared in horror at the scene before him. He didn't even see me. I don't know why, but he bent down and lifted up the bey's tarbush, which had rolled away into the flowers. He stood brushing it off and wiping it with the sleeve of his gallabiyya, saying over and over, "There is no strength or power, except in God."

(3)

$$
\text { وذات مرة ر أيت حربي وقد خلع جلبابه و أمسك فأساً حين كان بشاب يعزق الأرض لكي يعزق معه }
$$

Wa dẹata mar-ratin raPaytu ḥarbī wa qad xala\{a ğilbābahu wa amsaka fa?san hīna kāna bishāy yafzaqu al-?arda likay yafzaqa maShu

One day when Bishai was working in the field, I saw that Harbi had removed his gallabiyya and picked up a hoe in order to help him. 
(4)

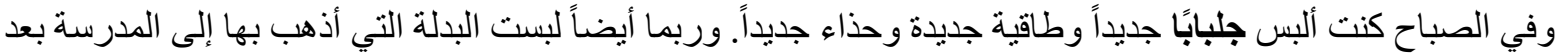

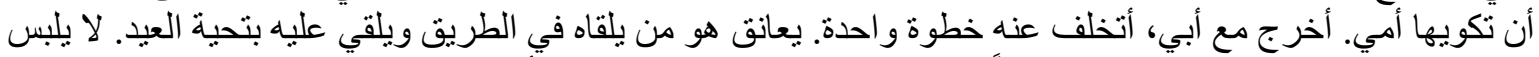

$$
\begin{aligned}
& \text { جلبابه في هذا اليوم، بل يلبس جبة وقفطاناً مكويين عند كو اء مخصوص في الني الأقصر يستخدم مكوة الرجل. }
\end{aligned}
$$

Wa fĩ aṣabāḥi kunto Ralbasu ğilbāban ğadīdan wa țāqiy-yatan ğadīda wa hịidāian ğadīdan. Wa rubbamā Rayḍan labistu al-badlata al-latī ?aḍhabu bihā ilā al-madrasati bǻda ?an takwīhā ?um-mī. Raxruğu maS Rabī, Rataxal-lafu Ranhu xutwatan wāhidatan. yưāniqu huwa man yalqāhu fī aț-țarīqi wa yulqī Yalayhi bitahịiy-yati al-\{īd. Lā yalbasu ğilbābahu fī hāḍa al-yawm, bal yalbasu ğub-batan wa qifțānan makwīyayni Sinda kaw-wa?in maxṣūṣin fī al-?aqșur yastaxdimu makwati al-riğl

In the morning I was wearing a new gallabiyya, skullcap, and shoes. I may also have been wearing the suit I went to school in, freshly ironed by my mother. I went out after my father, staying one step behind him. He embraced everyone he met in the street and gave him the traditional holiday greeting. On this day he wasn't wearing his gallabiyya. Instead he wore a jubbah and caftan, which had been ironed at a presser's shop in Luxor specializing in men's garments.

(5)

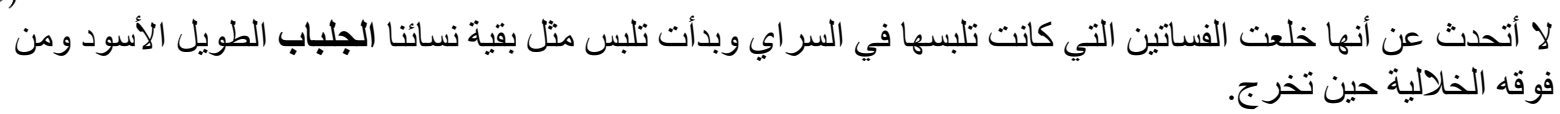

Lā Pataḥad-dațu San Pan-nahā xalaGat al-fasātīn al-latī kānat talbasuhā fĩ al-sarāy wa bada?at talbasu mița baqiy-yati nisā?ana al-ğilbāba al-țawīla al-Paswada wa men fawqihi al-xilāliy-yati hịna taxruğu

I'm not talking about the fact that she stopped wearing the dresses she had worn at the palace and began wearing, like the rest of our women, the long, black jilbaab with the peasant robe over it, any time she went out.

(6)

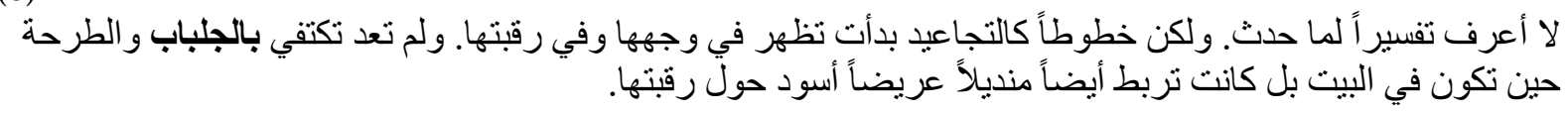

Lā Rårifu tafsīran limā ḥadaț. Wa lākin xuțūțan kat-tağāYīdi bada?at taẓharu fī wağhihā wa fī raqabatihā. Wa lam tafud taktafĩ bil-ğilbābi wa al-țarḥati țina takūnu fil bayti bal kānat Rayḍan tarbuṭu mindīlan Sarīụan ?aswadan ḥawla raqabatihā

I know no explanation for what happened. But lines, like wrinkles, began to appear on her face and neck. She no longer wore only the jilbaab and the veil when she was at home, but took to wrapping a wide black kerchief around her neck as well.

The issue here goes beyond the unjustified distinction in the TT between ğilbā $b$ and ğal-labiy-ya. Although in the SL ğal-labiy-ya and ğilbāb are used interchangeably to describe the same type of long, flowing garment for both men and women, ğilbāb has also taken on a more religiously-inclined nuance as the Islamic dress for women. This is the nuance which has been transferred into English, where the term jilbaab (or jilbab) has become widely accepted as the Islamic dress code for women due to the fact that the term was mentioned in the Quran in the context of women's modest dress. The term can be found in Muslim media targeting English-speaking Muslims, such as pamphlets and websites, as well as traditional Muslim 
jurisprudence texts, both modern and ancient, and publications discussing Muslim lives and issue in general (see: Renard (2012), Emon et al. (2012), O’Hagan (2006), Merali (2006), Ameli and Merali (2004), Abdul Rahman (2003), Al-Fauzan (2003), Samiuddin \& Khanam (2002), among others).

The fact that the translator of Aunt Safiyya and the Monastery chooses to use jilbaab for the dress worn by the female protagonist is problematic. It gives the dress a spiritual sense that does not exist in the ST, changing the frame reference from PERCEPTUAL $\rightarrow$ VISUAL $\rightarrow$ WOMEN'S_DRESS $\rightarrow$ UPPER_EGYPT and GENERIC $\rightarrow$ UPPER_EGYPTIAN_WOMAN to PERCEPTUAL $\rightarrow$ VISUAL $\rightarrow$ WOMEN'S_DRESS_MUSLIM, with the secondary frame references SOCIAL $\rightarrow$ INSTITUTIONAL $\rightarrow$ MODEST and GENERIC $\rightarrow$ MUSLIM_WOMAN. Whereas the ST terms ğal-labiy-ya and ğilbāb simply and interchangeably refer to the traditional dress worn by Upper Egyptian and Delta men and women, regardless of what faith they practice, the TT evokes a specific religious affiliation which does not exist in the ST. Besides the transliteration, the translator also uses the following glossary entries:

Table 1: Glossary Entries from the translated text of Aunt Safiyya and the Monastery

gallabiyya long robe-like garment, traditionally worn by Egyptian peasant men. In winter, other clothes might be worn underneath, including a pair of long underpants.

jilbaab long garment similar to a gallabiyya

The entries inaccurately define the ğal-labiy-ya as a garment worn exclusively by men, which may be true in other cultures where the ğal-labiy-ya is common, such as Sudan or Somalia, but not in Egypt, where the term applies to both genders, whereas it does not identify the ğilbāb as exclusive to women, although the usage within the translation of the text assumes this stance.

The frame congruence issue here is that the garment in question does not exist in the TL in the same manner that it does in the SL, which leaves a lexical/perceptual gap in the TT. Instead, the TL term used in reference to the garment has a radically different frame reference, which fills the void with the wrong frame reference and an inaccurate footnote, not only removing the appropriate reference, but also transplanting a misleading alternative. The frame reference of the SL, therefore, does not correspond to that of the TL, which leads to a quantifiably unsuccessful translation (Fig. 2): 
Table 2: Frame Congruence Analysis for ğilbāb in Aunt Safiyya and the Monastery

\begin{tabular}{|c|c|c|c|c|}
\hline SL & Frame Reference & TL & Frame Reference & 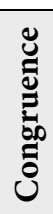 \\
\hline \multirow{6}{*}{ 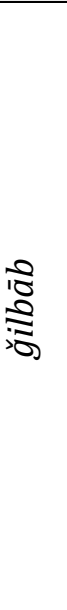 } & $\begin{array}{l}\text { PERCEPTUAL } \rightarrow \text { VISUAL } \rightarrow \text { ETHNIC_ } \\
\text { GARMENT } \rightarrow \text { MAN/WOMAN }\end{array}$ & gallabiyya & $\begin{array}{l}\text { PERCEPTUAL } \rightarrow \text { VISUAL } \rightarrow \text { ETHNIC_ }_{-} \\
\text {GARMENT } \rightarrow \text { MAN }\end{array}$ & - \\
\hline & $\begin{array}{l}\text { PERCEPTUAL } \rightarrow \text { VISUAL } \rightarrow \text { ETHNIC_ } \\
\text { GARMENT } \rightarrow \text { UPPER_EGYPT }\end{array}$ & (footnote) & $\begin{array}{l}\text { PERCEPTUAL } \rightarrow \text { VISUAL } \rightarrow \text { ETHNIC_ } \\
\text { GARMENT } \rightarrow \text { UPPER_EGYPT }\end{array}$ & + \\
\hline & - & \multirow[t]{4}{*}{ jilbaab } & $\begin{array}{l}\text { PERCEPTUAL } \rightarrow \text { VISUAL } \rightarrow \text { ETHNIC_ } \\
\text { GARMENT } \rightarrow \text { WOMAN }\end{array}$ & - \\
\hline & - & & $\begin{array}{l}\text { PERCEPTUAL } \rightarrow \text { VISUAL } \rightarrow \\
\text { WOMEN's_DRESS_MUSLIM }\end{array}$ & - \\
\hline & - & & $\begin{array}{l}\text { SOCIAL } \rightarrow \text { INSTITUTIONAL } \rightarrow \\
\text { MODEST }\end{array}$ & - \\
\hline & & & GENERIC $\rightarrow$ MUSLIM_WOMAN & - \\
\hline
\end{tabular}

The issue may be quite simply resolved by unifying the TL term in the same manner that was intended in the SL, either through the use of ğal-labiy-ya to avoid the religious connotations that come with $\breve{g} i l b \bar{a} b$, or through the use of $\breve{g} i l b \bar{a} b$ in addition to a more detailed footnote explaining the difference. Since the events take place in a part of the world where the term ğal-labiy-ya covers the garment worn by both genders, regardless of religious affiliation, it may be safer to transliterate both as ğal-labiy-ya and include an explanatory footnote to avoid adding any frame references not present in the ST.

\subsection{Zaat}

Zaat, on the other hand, references different types of ğal-labiy-ya (or ğilbāb, since the author uses them interchangeably), some of which have more social than geographical indications. The novel, which takes place in a strictly urban setting, uses the term ğal-labiy-ya to refer to a variety of garments:

(a) Loose garments worn by men and women at home. The men's garment resembles the traditional ğal-labiy-ya worn by men in the Delta and Upper Egypt, except it could also have short sleeves and more embellishments.

(b) White, loose garments, though less loose than the traditional Egyptian ğal-labiy-ya, different varieties of which are worn by men in Gulf states, also known as a tawb. In this particular text, the men who wear such garment are ones who assume a more religious air, usually a factitious one.

(c) A more ambiguous reference to a woman wearing a ğilbāb at a hospital, although it is hard to discern from the context whether the garment represents where the woman is from or her socioeconomic status. In an urban setting, a woman wearing a ğal-labiy-ya/ğilbāb outside the house is either expressing her geographical identity as belonging to the Delta or Upper Egypt, or belongs to a lower socioeconomic class. The definitions overlap since, 
in the deeply stratified SC, an individual from Upper Egypt or the Delta who is introduced into an urban setting is, more often than not, regarded as being socially inferior, regardless of economic status.

Although the author uses the term ğal-labiy-ya and ğilbāb interchangeably in the ST, the translator uses ğal-labiy-ya for both, possibly to avoid activating the RELIGIOUS frame observed in the previous section. However, this is done without providing an explanation of the term, which is not part of the English lexicon or the general awareness of the TL reader. This adds the problem of visualization blockage to the already existing issue of the TL reader's inability to appreciate the hidden social meaning of the garment in this particular text due to its complexity and the expected lack of profound knowledge of the SC, although it may be argued that the garment may be loosely visualized based on the context. Additionally, unlike Aunt Safiyya and the Monastery, where a ğal-labiy-ya is an expected garment in its natural environment, which was explained, albeit inadequately, at the beginning of the text in a glossary entry, Zaat's urban setting provides the optimal background for the author's use of the ğal-labiy-ya as a social device, adding a SOCIAL frame component to the preexisting PERCEPTUAL one. It must, therefore, be noted that the following analysis of the examples from Zaat entails the resolution of the PERCEPTUAL frame blockage in the TT by providing a footnote or a glossary entry before the text describing what a ğal-labiy-ya looks like, the latter being more practical due to the recurrence of the term throughout the text.

The success of the translation of the term ğal-labiy-ya/ğilbāb in Zaat, therefore, is dependent on the addition of supplementary information in the form of a footnote or in-text explanation of the garment in order to activate the SOCIAL frame and augment the PERCEPTUAL frame in order to resolve the semantic void seen in the figures below.

The first example, a description of a female patient at an impoverished inner city state-run hospital, has frame references that reflect SOCIAL indications along with the PERCEPTUAL frames, namely SOCIAL $\rightarrow$ SOCIAL_STATUS $\rightarrow$ INFERIOR and GENERIC $\rightarrow$ LOWER_SOCIOECONOMIC_STATUS (based on a combination of the garment and the settings), alongside the main PERCEPTUAL frame, PERCEPTUAL $\rightarrow$ VISUAL $\rightarrow$ WOMAN'S_DRESS:

(1)

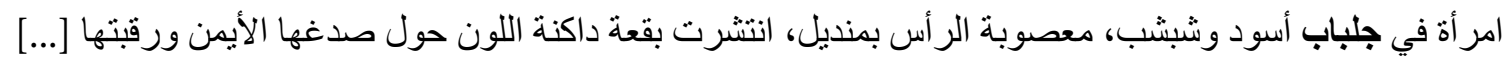

[...] ?imra?atun fi ğilbābib ?aswadin wa shibshib, maSṣūbati al-ra?si bi-mindīl, ?intašarat buqfatun dākinatun ḥawla șadgiihā al-?ayman wa raqabatuhā

[...] a woman in a black gallabiya and flip-flops with a scarf tied around her head, and a dark blotch extending over her right temple and neck 
Table 3: Frame Congruence Analysis for ğilbāb in Zaat (Example 1)

\begin{tabular}{|c|c|c|c|c|}
\hline SL & Frame Reference & TL & Frame Reference & 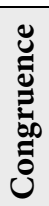 \\
\hline \multirow{3}{*}{ 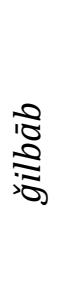 } & $\begin{array}{l}\text { PERCEPTUAL } \rightarrow \text { VISUAL } \rightarrow \\
\text { WOMAN'S_DRESS }\end{array}$ & \multirow{3}{*}{ 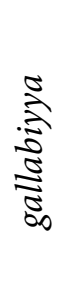 } & $\begin{array}{l}\text { PERCEPTUAL } \rightarrow \text { VISUAL } \rightarrow \\
\text { WOMAN'S_DRESS } \\
\text { (from context not lexical unit) }\end{array}$ & + \\
\hline & SOCIAL $\rightarrow$ SOCIAL_STATUS $\rightarrow$ INFERIOR & & - & - \\
\hline & $\begin{array}{l}\text { GENERIC } \rightarrow \text { LOWER_SOCIOECONOMIC_ } \\
\text { STATUS }\end{array}$ & & - & _ \\
\hline
\end{tabular}

In the next example, however, the social nuance is more subtle, as the image of the winceyette ğal-labiy-ya may be more commonly associated in the SC background of the ST reader familiar with Egyptian culture in the 1980's with a lower to lower-middle class background, activating the frame SOCIAL $\rightarrow$ SOCIAL_STATUS $\rightarrow$ INFERIOR and GENERIC $\rightarrow$ LOWER_SOCIOECONOMIC_STATUS. This is a frame that was easier to decode in the previous example based on the setting of the inner city hospital, which facilitates the activation of the LOWER_SOCIOECONOMIC_STATUS frame. The TT reader, on the other hand, is not able to invoke the same image for lack of SC background. This leads to a secondary SOCIAL frame void but not a major primary VISUAL one, as the context helps the TT reader recognize the garment as something resembling a housecoat.

However, the overall frame of the passage when Zaat visits her college friend Safiya, whose descent into poverty and squalor in her older years is decipherable throughout the entire scene, makes up for the missed subtle reference by having the same indication SOCIAL $\rightarrow$ SOCIAL_STATUS $\rightarrow$ INFERIOR, on which it elaborates with the details of Safiya's lower socioeconomic conditions:

(2)

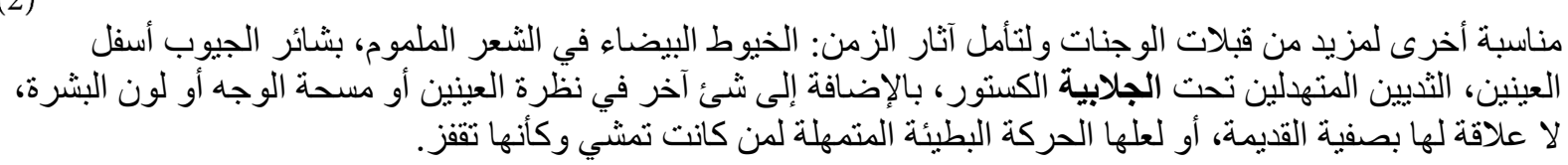

Munāsabatun Puxrā li-mazīdin min qublāt al-wağnāti wa li-ta?am-muli Tāțāri al-zaman: al-xuyūṭ al-bayḍā? fi aš-șafri al-malmūm, bašāîiri al-ğuyūbi asfal al-\{aynayn, at-țadyayni al-mutahaddilayni taḥta al-ğal-labiy-ya al-kastūr, bil-Piḍāfati Rilā šay?in ?āxarin fī naẓrati al-Saynayn ?aw masḥati al-wağhi ?aw lawn al-bašara, lā filāqata lahā bi-ṣafiy-ya al-qadīma, ?aw laSal-lahā al-ḥaraka al-bațîTa al-mutamah-hila li-man kānat tamšy wa-ka?an-nahā taqfiz

Another excuse for more kisses on the cheeks, and to contemplate the effects of time: the white strands in the tied-back hair, the signs of impending bags under the eyes, the sagging breasts under the winceyette gallabiya, as well as something else in the eyes, or the expression on her face, or the color of her skin that had nothing to do with the Safiya of long ago. Perhaps it was the slow deliberate movements of one who used to walk with a healthy spring in her step. 
Table 4: Frame Congruence Analysis for ğal-labiy-ya in Zaat (Example 2)

\begin{tabular}{|c|c|c|c|c|}
\hline SL & Frame Reference & TL & Frame Reference & 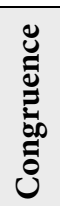 \\
\hline \multirow{3}{*}{ 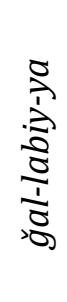 } & $\begin{array}{l}\text { PERCEPTUAL } \rightarrow \text { VISUAL } \rightarrow \\
\text { WOMAN'S_DRESS }\end{array}$ & \multirow{3}{*}{$\underset{\substack{5 \\
\frac{5}{3}}}{\stackrel{5}{0}}$} & $\begin{array}{l}\text { PERCEPTUAL } \rightarrow \text { VISUAL } \rightarrow \\
\text { WOMAN'S_DRESS } \\
\text { (from context not lexical unit) }\end{array}$ & + \\
\hline & SOCIAL $\rightarrow$ SOCIAL_STATUS $\rightarrow$ INFERIOR & & - & - \\
\hline & $\begin{array}{l}\text { GENERIC } \rightarrow \text { LOWER_SOCIOECONOMIC_ } \\
\text { STATUS }\end{array}$ & & - & - \\
\hline
\end{tabular}

On the other hand, another type of ğal-labiy-ya in Zaat comes with different frame references, PERCEPTUAL, GENERIC, and SOCIAL. This gallabiyya, a more form-fitting design commonly called tawb and worn by men in the Gulf, is used in this text as a marker of the neoreligious wave of Egyptians returning from the Gulf with imported ideologies and sensibilities, or otherwise as a sign of religiousness, be it authentic or factitious. These instances carry the main perceptual frame PERCEPTUAL $\rightarrow$ VISUAL $\rightarrow$ MEN'S_GARMENT $\rightarrow$ GULF, as well as the secondary frame GENERIC $\rightarrow$ RELIGIOUS (in the case of the first example) and SOCIAL $\rightarrow$ SOCIAL_STATUS $\rightarrow$ SUPERIOR and GENERIC $\rightarrow$ PRETENTIOUS (in the second example). The nonVISUAL frames are harder to translate, in which case the translator will rely on the TT reader's understanding of the underlying meaning of the text as a whole, rather than the interpretation of the term in isolation:

(3) a.

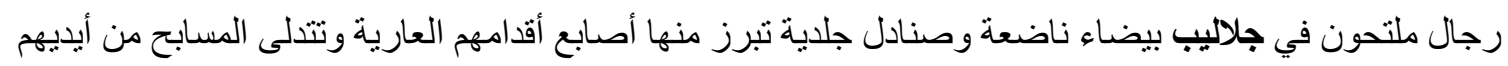

Riǧālun multaḥūn fī ğalalībin bayḍāin nāșiYati al-bayāḍ wa șanādilin ğildiy-yatin tabruzu minhā ?așābiSa Raqdāmihim al-\{āriya wa tatadal-lā al-masābiḥa min Paydīhim

Bearded men in gleaming white gallabiyas and leather sandals with their bare toes sticking out, prayer beads dangling from their hands [...]

b.

على وجه التحديد، استؤنفت المقاطعة في أعقاب زيارة من ذات و عبد المجيد لابن عمته، في شقة أمه المتو اضعة بأحد أزقة

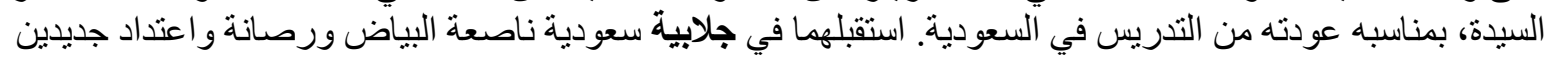

عليه (..)

Salā wağhi al-taḥdīdi, esto?nifat al-muqāṭaYatu fĩ Råqābi ziyāratin men dāat wa Sabdilḥamīdi l-ibni Sam-matihi, fĩ šaq-qati ?um-mihi al-mutawādiSa be-Paḥadi Paziq-qati al-say-yida be-munāsabat Sawdatihi min al-tadrīsi fĩ as-suYūdiy-ya. Istaqbalahumā fī ğal-labiy-yatin saYūdiy-yatin nāṣiYat albayāọ wa rașānatin wa îtidādin ğadīdayni Salayh [...]

To be precise, the boycott was resumed after a visit by Zaat and Abdel Maguid to his cousin, who lived with his mother in a humble flat in a small alley in Sayyeda Zeinab, on the occasion of his return from Saudi Arabia where he had been working as a teacher. He greeted them in a gleaming white Saudi gallabiya, and with a composure and confidence that he had not had before. 
Table 5: Frame Congruence Analysis for ğal-labiy-ya in Zaat (examples $3 a$ and 3b)

\begin{tabular}{|c|c|c|c|c|}
\hline SL & Frame Reference & TL & Frame Reference & 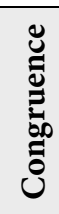 \\
\hline \multirow{3}{*}{$\begin{array}{l}\frac{0}{1} \\
\frac{\pi}{2} \\
\frac{0}{0} \\
\frac{1}{5} \\
0\end{array}$} & $\begin{array}{l}\text { PERCEPTUAL } \rightarrow \text { VISUAL } \rightarrow \\
\text { MEN'S_GARMENT } \rightarrow \text { GULF }\end{array}$ & \multirow{3}{*}{ 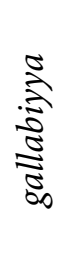 } & $\begin{array}{l}\text { PERCEPTUAL } \rightarrow \text { VISUAL } \rightarrow \text { GARMENT } \\
\text { (from context not lexical unit) }\end{array}$ & $+/-$ \\
\hline & GENERIC $\rightarrow$ RELIGIOUS (3.A) & & Context & $+/-$ \\
\hline & $\begin{array}{l}\text { SOCIAL } \rightarrow \text { SOCIAL_STATUS } \rightarrow \text { SUPERIOR } \\
\text { (3.B.) }\end{array}$ & & Context & $+/-$ \\
\hline
\end{tabular}

As can be surmised from the data in the chart, the interpretation of the PERCEPTUAL, as well as the SOCIAL frame in these two examples relies largely on context rather than the inherent frame reference of the lexical unit itself, in which case the congruence rate depends on whether the TT reader succeeds at capturing the nuances of the text without further explanation on the part of the translator.

A third type of ğal-labiy-ya in Zaat is the doorman's display of his regional origins in the form of a full Upper Egyptian outfit, including the Upper Egyptian ğal-labiy-ya. In the ST, the term بلدياته baladìy-yātuh, meaning compatriot (which could be used in reference to any region in Egypt, but is more commonly used in reference to Upper Egypt), along with the general description of the man's outfit, provide a subtle hint to the region from which he comes, hence providing a context for the ğal-labiy-ya. In the TT, the translator avoids the subtlety by transforming the hints into an open statement that the man and his companions were from Upper Egypt, which decodes the frame reference GENERIC $\rightarrow$ UPPER_EGYPTIAN_MAN:

(4)

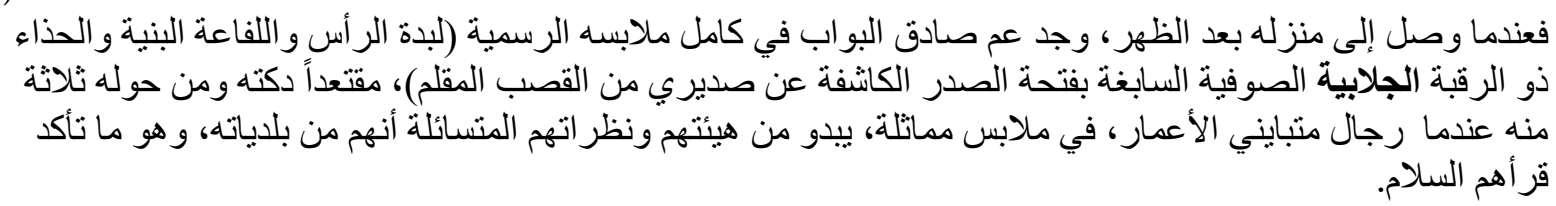

Fa-\{indamā wașala Pilā manzilihi bałda al-ẓuhri, wağada Samm șādiq al-baw-wāb fī kāmili malābisihi ar-rasmiy-ya (libdati ar-ra?si wa al-lifāSati al-bun-niy-ya wal-ḥid̄ā?i dū ar-raqabati walğal-labiy-yati aṣ-șūfiy-yati as-sābig̉ati bi-fatḥati aṣ-șadri al-kāšifati Yan șidīriy-yin min al-qașabi almuqal-lami), muqtaSidan dik-katihi wa men ḥawlihi țalātati riğālin mutabāyini al-Paßmār fī malābisin mumātila yabdū min hay?atihim wa naẓarātihim al-mutasā?ila ?an-nahum min baladiyyātih, wa huwa mā ta?ak-kada min-hu Sindamā qara?ahum as-salām.

For when he arrived home that afternoon, he found Amm Sadeq the bawwab dressed in his official regalia (felt skullcap, brown scarf, boots, and long wide woolen gallabiya open at the chest to reveal a striped waistcoat underneath) sitting on his bench with three men of different ages wearing similar clothes standing around him. Their appearances and questioning, bewildered expressions indicated that they too were from Upper Egypt and only recently arrived in the city. This was confirmed when Abdel Maguid gave the Islamic greeting. 
Table 6: Frame Congruence Analysis for ğal-labiy-ya in Zaat (example 4)

\begin{tabular}{|c|c|c|c|c|}
\hline SL & Frame Reference & TL & Frame Reference & 苛 \\
\hline \multirow{2}{*}{$\begin{array}{l}\frac{0}{1} \\
\stackrel{3}{\overrightarrow{0}} \\
\frac{1}{\frac{1}{1}} \\
\frac{1}{0}\end{array}$} & $\begin{array}{l}\text { PERCEPTUAL } \rightarrow \text { VISUAL } \rightarrow \\
\text { ETHNIC_GARMENT } \rightarrow \text { MAN }\end{array}$ & \multirow{2}{*}{ 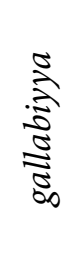 } & $\begin{array}{l}\text { PERCEPTUAL } \rightarrow \text { VISUAL } \rightarrow \text { ETHNIC_ } \\
\text { GARMENT } \rightarrow \text { MAN }(\text { Context) }\end{array}$ & + \\
\hline & $\begin{array}{l}\text { PERCEPTUAL } \rightarrow \text { VISUAL } \rightarrow \\
\text { ETHNIC_GARMENT } \rightarrow \text { UPPER_EGYPT }\end{array}$ & & $\begin{array}{l}\text { PERCEPTUAL } \rightarrow \text { VISUAL } \rightarrow \text { ETHNIC_ } \\
\text { GARMENT } \rightarrow \text { UPPER_EGYPT } \\
\text { (in-text explanation) }\end{array}$ & + \\
\hline
\end{tabular}

According to the frame congruence chart, this may be considered the most successful translation of the term ğal-labiy-ya in the TT, since it manages to convey the full range of ST frame references using both contextual clues and in-text explanation.

\subsection{Taxi}

Taxi, a novel based on true events, recounts the author's numerous taxi rides in Cairo and his conversations with the drivers, reflecting everything from the Egyptian socio-political climate in the twenty-first century to the drivers' personal anecdotes and views on soccer and marriage. Accordingly, the setting of the text, just like Zaat, is almost exclusively urban except for the one mention of the author's trip to a rural community where he encounters a woman in a ğal-labiy-ya. The translation of the SL term is treated in a third way, which is translating the description of the garment rather than its name, thus transferring the full range of frame reference using both in-text explanation and contextual clues:

$$
\text { ومرت من جانبي امر أة جميلة تلبس جلابية قروية ويتدلى من أذنيها قرط من المركز. }
$$

Wa mar-rat bi-ğānibī imra?atun ğamīlatun talbasu ğal-lābiy-yatan qarawiy-yatan wa yatadal-lā min Pudunayhā qirțun min al-markazi

A beautiful woman walked past me wearing a long village-style dress and pendant earrings bought from the nearest provincial centre hanging from her ears. 
Table 7: Frame Congruence Analysis for ğal-labiy-ya in Taxi

\begin{tabular}{|c|c|c|c|c|}
\hline SL & Frame Reference & TL & Frame Reference & 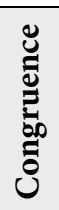 \\
\hline \multirow{3}{*}{ 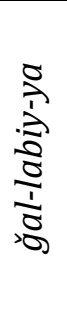 } & $\begin{array}{l}\text { PERCEPTUAL } \rightarrow \text { VISUAL } \rightarrow \text { ETHNIC_ } \\
\text { GARMENT } \rightarrow \text { WOMAN }\end{array}$ & \multirow{3}{*}{ 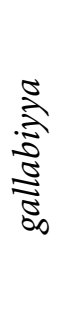 } & $\begin{array}{l}\text { PERCEPTUAL } \rightarrow \text { VISUAL } \rightarrow \text { ETHNIC_ } \\
\text { GARMENT } \rightarrow \text { WOMAN }\end{array}$ & + \\
\hline & $\begin{array}{l}\text { PERCEPTUAL } \rightarrow \text { VISUAL } \rightarrow \text { WOMEN'S_ } \\
\text { GARMENT } \rightarrow \text { EGYPTIAN_VILLAGE }\end{array}$ & & $\begin{array}{l}\text { PERCEPTUAL } \rightarrow \text { VISUAL } \rightarrow \text { WOMEN'S_ } \\
\text { GARMENT } \rightarrow \text { EGYPTIAN_VILLAGE }\end{array}$ & + \\
\hline & $\begin{array}{l}\text { GENERIC } \rightarrow \text { EGYPTIAN_PEASANT_ } \\
\text { WOMAN }\end{array}$ & & $\begin{array}{l}\text { GENERIC } \rightarrow \text { EGYPTIAN_PEASANT_ } \\
\text { WOMAN }\end{array}$ & + \\
\hline
\end{tabular}

This provides the reader with a chance to visualize the dress worn by the woman as a traditional village-style garment and, instead of leaving the TT reader wondering what a ğal-labiy-ya was, it would be possible to imagine something corresponding to the frame PERCEPTUAL $\rightarrow$ VISUAL $\rightarrow$ WOMEN'S_GARMENT $\rightarrow$ EGYPTIAN_VILLAGE and GENERIC $\rightarrow$ EGYPTIAN_ PEASANT_WOMAN.

\section{Conclusion}

The use of semantic frames to quantify the accuracy and success of a translation is a simple and convenient method to compare the ST and the TT in terms of the number of semantic frames encoded in each and the number of frames the TL reader is capable of decoding based on the TT. The more congruent the ST and TT semantic frames are, the more accurate the outcome is. Utilizing this method by translators and editors will increase the chance of producing a TT that is closer to the intended meaning of the ST, which guarantees a richer, more colorful experience for the TL reader, who is now capable of decoding the same message in the TT that the SL reader can decode in the ST.

This is especially important in the case of VISUAL frames, which play a pivotal role in the transmission of the wide array of elements forming a scene in a narrative text, helping the TL reader visualize the events and the elements which constitute the scene. Although inaccuracy is transmitting VISUAL frames may, at times, seem trivial, especially compared to more extensive frames, such as SOCIAL or GENERIC frames, the extent to which it impacts the TL reader's understanding of the TT varies depending on the extent of inaccuracy and the importance of the description in the context of the text.

\section{References}

\section{Primary Arabic Sources}

Alkhamissi, K. (2011). Taxi. Cairo: Dār ash-shurūq. Ibrahim, S. (2003). Dāt. Cairo: Dār al-Mustaqbal al-Sarabī. Taher, B. (1996). Xaltī șafiy-ya wad-dìr. Cairo: Dār al-Hilāl. 


\section{Primary English Sources}

Alkhamissi, K. (2011). Taxi. (J. Wright, Trans.). Doha: Bloomsbury Qatar Foundation Publishing. Ibrahim, S. (2001). Zaat. (A. Calderbank, Trans.). Cairo: American University in Cairo Press.

Taher, B. (1996). Aunt Safiyya and the Monastery. (B. Romaine, Trans.). Berkeley: University of California Press.

\section{Secondary Sources}

Abdul-Baquee, S., \& Atwell, ES. (2009). Knowledge representation of the Quran through frame semantics: a corpus-based approach. In Proceedings of the Fifth Corpus Linguistics Conference. The Fifth Corpus Linguistics Conference, 20-23 July 2009, University of Liverpool, UK.

Abdul Rahman, M.S. (2003). Islam: Questions and Answer, vol. 10. London: MSA Publication Limited.

Al-Fauzan, S. F. (2003). Rulings Pertaining to Muslim Women. Riyadh: Maktaba Dar-us-Salam.

Ameli, S., \& Merali, A. (2004). British Muslims' Expectations of Government, Volume 2. London: Islamic Human Rights Commission.

Boas, H. C. (2002). Bilingual FrameNet dictionaries for machine translation. In M. González Rodríguez \& C. Paz Suárez Araujo (Eds.), Proceedings of the Third International Conference on Language Resources and Evaluation, Vol. 4 (pp. 1364-1371). Las Palmas, Spain.

Boas, H. C. (2003). A constructional approach to resultatives. Stanford, CA: CSLI Publications.

Boas, H. C. (2005). From theory to practice: Frame semantics and the design of FrameNet. In S. Langer \& D. Schnorbusch (Eds.), Semantik im Lexikon (pp. 129-160). Tübingen: Gunter Narr.

Boas, H. C. (2013). Frame Semantics and Translation. In Ana Rojo and Iraide Ibarretxe-Antuñano (Eds.), Cognitive Linguistics and Translation. Berlin: Mouton De Gruyter.

Burchardt, A., Erk, K., Frank, A., Kowalski, A., Pado, S., \& Pinkal, M. (2009). FrameNet for the semantic analysis of German: Annotation, representation, and automation. In Hans Boas (Ed.), Multilingual FrameNet. Berlin: Mouton de Gruyter.

Emon, A., Ellis, M., \& Glahn, B. (Eds.) (2012). Islamic Law and International Human Rights Law. Oxford: Oxford University Press.

Fillmore, C. J., \& Atkins, B. T. S. (2000). Describing polysemy: The case of 'crawl'. In Y. Ravin \& C. Leacock (Eds.), Polysemy (pp. 91-110). Oxford: Oxford University Press.

Gärdenfors, P. (1999). Some Tenets of Cognitive Semantics. In J. Allwood \& P. Gärdenfors (Eds.) Cognitive Semantics: Meaning and Cognition. Amsterdam: John Benjamins.

Merali, A. (2006). Hijab, Meaning, Identity, Otherization and Politics: British Muslim Women. London: Islamic Human Rights Commission.

O'Hagan, K. (2006). Identifying Emotional and Psychological Abuse: A Guide for Childcare Professionals. Berkshire: Open University Press.

Ohara, K., Fujii, S., Ohoro, T., Suzuki, R., Saito, H., \& Ishizaki, S. (2004). The Japanese FrameNet Project: An Introduction. LREC 2004: The Fourth International Conference on Language Resources and Evaluation. Lisbon, Portugal. May, 2004.

Petruck, M. R. L., \& Boas, H. C. (2003). All in a day’s week. In E. Hajicova, A. Kotesovcova \& J. Mirovsky (Eds.), Proceedings of CIL 17. Prague: Matfyzpress.

Renard, J. (2012). The Handy Religion Answer Book. Detroit: Visible Ink Press.

Rojo, A. M. (2002a). Applying frame semantics to translation: A practical example. Meta: Translators' Journal 4.3, $312-50$.

Rojo, A. M. (2002b). Frame semantics and the translation of humor. Babel 48(1), 34-77(44).

Samiuddin, A., \& Khanam, R. (2002). Iraq, Palestine, Saudi Arabia, Turkey, vol. 3. Chicago: Northwestern University.

Subirats, C., \& Petruck, M. (2003). Surprise: Spanish FrameNet. International Congress of Linguists. Workshop on Frame Semantics, Prague (Czech Republic), July 2003.

Vega de, M. (1984). Introducción a la Psicología Cognitiva. Madrid: Alianza. 